\title{
Students' Inherent Characteristics as Correlates of Academic Performance in Mathematics Education in Enugu State, Nigeria
}

\author{
Iketaku Ifeoma $\mathbf{R}$ \\ Department of Educational Psychology, Enugu State College of Education Technical (ESCET),Nigeria \\ Ani Mercy Ifunanya \\ Department of Science Education, University of Nigeria,Nsukka-Nigeria \\ Onyia Comfort Ngozi
}

Department of Chemistry, Enugu State College of Education (Technical), Enugu-Nigeria

\section{Doi:10.5901/mjss.2014.v5n26p93}

\begin{abstract}
The purpose of this study is to look at student inherent characteristics (gender and age) as correlate to academic performance in mathematics education. To carry out this, two research questions and one null hypothesis were stated. The correlation survey design was adopted for this study. The study analyzed data collected from two hundred students randomly drawn from two selected secondary schools in Enugu metropolis. The statistical tools employed to analyze the data collected were descriptive and inferential statistics while t-test statistics was used to test the null hypothesis. The results among other things revealed that no significant relationship exists between the students' inherent characteristics and their academic performance. Some suggestions and recommendations were given in the light of the research findings
\end{abstract}

Keywords: Students, Inherent Characteristics, Academic Performance, Mathematics.

\section{Introduction}

The enviable position which Mathematic Education system of nations of the world including Nigeria occupies is perhaps justifiable. This is so because; Mathematics touches completely all facts and spheres of human endeavour. Mathematics is a core subject that influences the life of the individual as well as the development effort of a nation (Emoven, 1985). In addition, Mathematics is a very important school subject that affects all aspects of life at different categories. It is the bedrock of all science and technologically based subjects (Maliki, Nyban and Ibu, 2009). Mathematics is also the foundation of any technical development of any Nation (Azuka, 2009).

The proper teaching of well designed and highly articulated Mathematics curricula is a sine quo non for the attainment of high academic performance. Academic performance has been described as the scholastic standing of a student at any given moment which could be explained in terms of the grades obtained in a course or groups of courses (Adeyemi, 1998). Simkins in (Adeyemin, 2011) argues that the main outputs in education are expressed in terms of learning that is, changes in knowledge skills and attitudes of individual as a result of their experiences within the school system. The researchers argue that the student's academic performance is the outcome of mathematics tests which depend on how much interest the students have in the subjects. The researcher also emphasized that without sound background and good adoption of application of relevant mathematics in the country there would be poor performance and zero progress technologically and equally no prospector success in any career. The researchers were of the opinion that mathematics teaching can only be result-oriented, when students are willing and the teachers are favourably disposed, using the appropriate methods and resources in teaching the students. With the current increase in scientific knowledge; all over the world; much emphasis is place on students' inherent factors as it concerns gender and age. Inherent factors are a permanent part of something belonging by nature as in age and gender.

Literature reveals that many researchers have indicated that there are numerous determinant factors ranging from students interest and attitude (Sandra,2002; Adoda \& Gbore; 2012, Acceladojo, 2001), teaching methods (Eniajeju, 2010), socio economic status (Ajayi \& Muraina 2011); gender (Balogun 1994, Owulabi and Etuk Iren 2009) and lack of good textbooks (Adepoju 2002) among others. Due to the quest for better academic performance of students at all level 
of education, researchers have continued to be improved upon by standing joint effect of predictor variables which this study is one of such. Many studies on gender factor in mathematics education abound (Agwagah \& Harbor Peters 1994; Ogunkola 2004) and really there exists gender on students performance in mathematics (Alebiosu, 2003). Certain factors are attributed to gender gaps and stereotyped images of sexes in school.

Agwagah \& Harbor -Peters (1994) reported that gender related differences existed in mathematics learning and achievement. In addition, Mills (1993); and Busch, (1995) in separate studies found out that boys clearly perform better than girls in mathematics test. They also reported that female students have significantly lower self - efficacy than males with respect to mathematics related and other traditionally male dominated subjects including computer science education other researchers have reported no significant gender differences in academic performance in mathematics Adegboye (1998); Wit- Rose (2003); Grassi(2004); Abubakar and Eze (2010).

Another observable trait-"age" has been reported to have significant influence on achievement in mathematics. Agwagah and Habor-Peters (1994), have reported that little differences are identified between males and females in mathematics achievement at ages 9 through 13 years but at ages 17 females perform poorer than the males. Tenzin (2002) reported that younger students outperformed their peers in mathematics and other subjects while the older students achieved at a higher level than the younger ones. Hence, age could be seen as a predictor of success that that leads to high academic performance.

The above literature reveals that student's inherent factors - gender and age have a contributing effect on student's academic performance. Therefore this study sought to find out the students inherent factors (gender and age) as correlates of academic performance in mathematics education in Enugu state, Nigeria

\subsection{Purpose of the Study}

The purpose of this study was to investigate on the student inherent factor gender and age as correlate of academic performance in mathematics education. Also finding the constraints and then making recommendation to improve on the student's academic performance in Mathematics

\subsection{Scope of the Study}

The study was focused on the inherent factors (gender and age) which affect the students' academic performance in mathematics education it was carried out in Enugu metropolis of Enugu state, Nigeria.

\subsection{Research Questions}

The following research questions were formulated to guide thestudy:

1. What is the individual contribution of each of the two predictor variables age and gender to student's academic performance?

2. What is the relationship between the students' inherent characteristics (gender and age) and their academic performance in mathematics?

\subsection{Research Hypothesis}

$\mathrm{HO}_{1}$ : There is no significant relationship between the student's inherent factors and their academic performance in Mathematics.

\section{Method}

The design of this study was correlational survey research design. This type of study seeks to establish what relationship exists between two or more variables (Nworgu, 2006). This study was carried out in Enugu Metropolis in Enugu State, Nigeria. The population of this study comprised all the secondary schools in Enugu metropolis in Enugu State Nigeria. The simple random sample technique was used for this study. The secondary schools in Enugu metropolis comprised of Technical and Grammar schools. Two secondary schools were chosen from both the Technical and Grammar schools by balloting since each of them have equal chance of being used for the study. A sample of two hundred students with age ranged from 13 to 20 constituted the sample for the study. The data was obtained from the results collected from the examination officer and teacher from the two secondary schools used in this study. Structured questionnaires prepared 
by the researchers containing 49 items in which a four point Likert score were used. The student's scores were correlated with their responses in the questionnaires. These two score were weighted added and then correlated using person product(r) formula.The descriptive and inferential statistics were used to answer the research question and the person product moment coefficient was used to answer the research question. The t test statistics was used in testing the hypothesis at 0.05 level of significance. The students responses on the questionnaire $(X)$ were computed against their academic performance scores $(\mathrm{Y})$ using the Pearson product moment correlation coefficient $(r)$ formula as follows:

$r=$

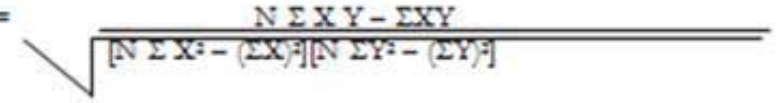

Where:

$E=$ Summation sign/sigma

$X=$ Responses on the questionnaire

$\mathrm{Y}=$ Academic performance scores

$\mathrm{N}=$ Number of Respondents

$r=$ Correlation coefficient value

In order to test for the significance of the value of correlation coefficient (r), a t-score was calculated and tested at probability level of 0.05 . The r-values were transformed to t-scores using the following formula:

$\mathrm{N}=$ Number of respondents

$$
t=\frac{\mathrm{r} \sqrt{\mathrm{N}-2}}{1-\mathrm{r} 2}
$$

$\mathrm{N}-2$ = Degree of Freedom

$r=$ Value of Correlation Coefficient

\section{Result and Discussions}

\subsection{Research Question}

1. What is the individual contribution of each of the two predictor variables (age and gender to academic performance in mathematical education?

Table 1a:Percentage contribution of age to academic performance in mathematics

\begin{tabular}{|c|c|c|}
\hline Age group & Number & $\%$ \\
\hline $13-14$ & 13 & $6.5 \%$ \\
\hline $15-16$ & 52 & $26.0 \%$ \\
\hline $17-18$ & 115 & $57.5 \%$ \\
\hline $19-20$ & 20 & $10.0 \%$ \\
\hline Total & 200 & $100.0 \%$ \\
\hline
\end{tabular}

Table 1b: Percentage contribution of gender to student's academic performance in mathematics

\begin{tabular}{|c|c|c|}
\hline Gender & No & $\%$ \\
\hline Female & 118 & $59 \%$ \\
\hline Male & 82 & $41 \%$ \\
\hline Total & 200 & 100 \\
\hline
\end{tabular}

The researchers divided the respondents into four age groups/ categories ranging from 13 -14 years 15-16years, 1718years and 19-20 years. Table 1a indicated that the largest number of respondents were in the age group of $17-18$ years with $(n=115,57.5 \%)$. The second largest group was the 15-16 years with ( $n=52,26.0 \%)$ of the respondents indicating their age in this group. The smallest number of respondents were in the age group of 13-14years with ( $n=13$, $6.5 \%)$. Table $1 b$ above also indicated that there were $(n=118,59.0 \%)$ females compared to $(n=82,41.0 \%)$ males from the samples.

Research questions 2: what is the relationship between the student's inherent factors (age and gender and their academic performance in mathematics education? 
Table 2: Summary of Pearson's r- value showing level of relationship between the student's inherent factors and their academic performance in mathematics.

\begin{tabular}{|c|c|c|c|c|c|}
\hline $\mathrm{X}$ & $\mathrm{Y}$ & $\mathrm{X}^{2}$ & $\mathrm{Y}^{2}$ & $\mathrm{XY}$ & $\mathrm{r}$ \\
\hline 8435 & 9730 & 359146 & 484427 & 412778 & 70.32 \\
\hline
\end{tabular}

The result on table 2 above revealed a positive but low correlation coefficient value of 0.32 .

\section{Testing Hypothesis}

Ho: There is no significant relationship between the students' inherent factors and their academic performances in mathematics

Table 3:Correlation coefficient ad t-test significant relationships between the students' inherent characteristics and their academic performances in mathematics

\begin{tabular}{|c|c|c|c|c|c|c|}
\hline $\mathrm{N}$ & $\mathrm{r}$ & $\mathrm{DF}$ & t-cal. & t-crit. & Decision & $\mathrm{r}^{2}$ \\
\hline 200 & 0.32 & 198 & 5.96 & 1.69 & Reject & 0.1024 or $10 \%$ \\
\hline
\end{tabular}

Table 3 above revealed that $t$ calculated was 5.96 which are greater than the critical t-value of 1.96 indicating rejection of the null hypothesis. Hence student's inherent factor was insignificant to the academic performance in mathematics. This implies that there is no significant relationship between the students inherent characteristics gender and age and the academic performance in mathematics. The works of Abubakar and Eze (2010) reported no significant gender difference in their studies.

\section{Recommendation}

Based on the findings some recommendations were made which hopefully will improve the student's inherent factor and academic performance in mathematics

- The government at all levels should encourage gender equity by giving scholarship and making adequate provision for students to participate in mathematical activities.

- The school authorities should monitor teacher and check their attendances to classes.

- Professional bodies (STAN) and experts should try to write textbooks to ensure content uniformity with the curriculum.

- Teacher should vary methods of teaching mathematics. They should be dedicated to their duty and motivates their students. Teachers should also make their lessons interesting participatory and students-centered

\section{Conclusion}

This research contributed to the broad understanding of the connectedness of student's inherent characteristics: age and gender on academic performance in mathematics. It sought to establish the significance and relational effect of age and gender on academic performance in mathematics. The data have provided evidence of a positive correlation between age gender and their academic performance. Both age and gender are both insignificant in academic performance of a student but age was a better contributor to academic performance. These findings reiterate the success of the increasing clamour for gender equity at all levels of education which the MDGs advocate for.

\section{References}

Abubakar, R.B \& Eze, F.B (2010).Female Students' Academic Performance in Mathematic at Federal College of Education (Technical) Omoku, Rivers State.International Journal of Social and Policy Issues. 6(1\&2), 48-53.

Adeboye, A. (1998). Predictive validity of the Junior Secondary School Certificate Examinations (JSCE) for Academic Performance in Senior Secondary School Certificate Examination (SSCE) in Ekiti State Nigeria, Unpulished M.Ed. Thesis, University of Ado-Ekiti.

Adepoju, T. (2002). Location Factors as Correlates of Private and Academic Performance of Secondary Schools in Oyo State. A 
Proposal (Presented at the Higher Students Joints Staff Seminar). Derpartment of teacher education, university of Ibadan, Ibadan.

Adeyemi T.O (1998). School and Teachers Variables associated with the Performance of Students in Ondo State, Nigeria. Unpublished Ph.D Thesis, University of Hull. United Kingdom.

Adodo, S.O \& Gbore, L.O (2012), Prediction of Attitude and Interest of Science students of Different Ability on their Academic Performance in Basic Science.

Agwagah, U.N.V \& Harbor-Peters V.F (1994). Gender Difference in MathematicsAchievement. Journal of Education and Psychology in Third World Africa 1(1), 19-22.

Ajayi .I.A (1998). Unit cost of Secondary Education and Students Academic Achievement in Ondo State, Nigeria (1991-1995) Unpublished Ph.D Thesis, university of Ibadan, Ibadan.

Alebiosu, K.A (2008). Perspectives in Provisions for Science and TechnologyEducation in Nigeria: The Way Forward (6:4).

Azuka, B.F. (2009). Implementation of the UBE Mathematics Curriculum for the Attainment of the millennium Development Goals. Lecture Notes on workshop for the Retraining of Primary School Teachers in the New Implementation of UBE Curriculum and continuous Assessment in Schools. Marvelous Mike Press Ltd. Garriki Abuja.

Balogu, T.A (1994). Gender Issues in the Teaching of Science, Technology and Mathematics.

Busch, T.(1995). Gender Difference in Self Efficacy and Academic Performance Among Students of Business Administration. Scndinavian Journal of Educational Research, 39, 311-318.

Emoven, E.U(1985). Sciencing the Nigerian Experience.The Practice of Science in Nigeria. Keynote Address, Proceedings of the $26^{\text {th }}$ Annual Conference of Science Teachers Association of Nigeria.Pp7-12.

Grambs, L.D (1972). Sex Sterotypes in Instructional Materials in Literature and language. A survey of Research women Study Abstract, 1: $1-4$.

Grassi, C. (2004).gender Based Achievement Self Confidence and Enrolment Gaps: mathematics at Trinity College:http://www.trincoll.edu/depts./educ/Research/Grassi.pdf.

Maliki, A. E, Nyban, A.N \& Ibu, J.E (2009).Analysis of Students'Performance in Junior Secondary School Mathematics Examination in Bayelsa State of Nigeria. Study Home Comm.Sci, 3(2): 131-134.

Mills,A. (1993). Gender Difference in Academically Young Students in Mathematics Reasoning Patterns Acrosss Age and Sub-skills. Journal of Education Psychology, 2, 340-346.

Nworgu, B.G (2006). Educational Research: Basic Issues and Methodology (Second \& Enlarged edition).university Trust Publishers, Nsukka. Enugu.

Ogunkola, B.J (2004). Students' Inherent characteristics, Parents,Educational Attainment and Family Size as Predictors of Academic Achievement in Integrated Science.

Sandra, D. (2002). Mathematics and science achievement: effects of motivation, interest and academic engagement. Journal of Educational Research. Available at: http://www.findarticles.com[Accessed 07/09/2006].

Witt-Rosw, D.L (2003). Students Self-efficacy in College Science. An Investigation of Gender, Age, and Academic Achievement, Unpublished M.Sc. Thesis of University of Wisconsinstout.

http:www.UNstout.edu/lib/thesis/2003/witt.rosedpdf. 